\title{
Neurogenic Effect of $\beta$-Amyloid Peptide in the Development of Neural Stem Cells
}

\author{
Miguel A. López-Toledano and Michael L. Shelanski \\ Taub Institute for Research on Alzheimer's Disease and the Aging Brain and Department of Pathology, Columbia University, New York, New York 10032
}

The adult mammalian brain contains neural stem cells (NSCs) with self-renewal and multilineage potential in the hippocampus and subventricular zone. However, neurogenesis from these areas does not compensate for neuronal loss in age-related neurodegenerative disorders such as Alzheimer's disease (AD). To test whether an impairment of neurogenesis could contribute to the pathogenesis of AD, we examined the effects of amyloid- $\beta$ peptide $(\mathrm{A} \beta)$ on the survival and neuronal differentiation of cultured NSCs from striatum and hippocampus. We show that $\mathrm{A} \beta$ peptide does not impair the neurogenic rate in NSC progeny, but that it increases the total number of neurons in vitro in a dose-dependent manner. The neurogenic effect of $\mathrm{A} \beta$ peptide is not dependent on soluble factors released from the NSC progeny. Neurogenesis is induced by $\mathrm{A} \beta 42$ and not $\mathrm{A} \beta 40$ or $\mathrm{A} \beta 25-35$, and the activity appears to be a property of $\mathrm{A} \beta$ oligomers and not fibrils.

These results suggest that $\mathrm{A} \beta$ may have positive as well as deleterious actions, and that a knowledge of the mechanisms involved in the former could be valuable in exploiting the regenerative and plastic potential of the brain in preventing and treating Alzheimer's disease.

Key words: Alzheimer; differentiation; hippocampus; stem cells; neurogenesis; amyloid $\beta$ peptide

\section{Introduction}

Over the past decade, it has become clear that new neurons are generated in a number of areas in the postnatal mammalian brain. In the dentate gyrus of the hippocampus, neurogenesis is still detectable in old age, although the rate of neurogenesis decreases during normal aging (Kuhn et al., 1996). This decrease in neurogenesis could be involved in the age-related decline in hippocampus-dependent learning (Kempermann et al., 1998). It has been suggested that neurogenesis is required for some types of memory and learning (Gould et al., 1999; Shors et al., 2001). It also has been shown that several pathological conditions (ischemia, epilepsy, and trauma) seem to upregulate neural stem cell (NSC) activity in the subventricular zone (SVZ) and dentate gyrus (for review, see Kuhn et al., 2001). These findings suggest that neural stem cell populations might be affected in Alzheimer's disease $(\mathrm{AD})$.

To approach this question, we studied the effect of the $\beta$-amyloid peptide $(\mathrm{A} \beta)$ on the proliferation, survival, and differentiation of NSCs in culture. The increased production of $A \beta$, or its decreased clearance, seems to play a major role in the development of $\mathrm{AD}$ (Yankner, 2000). A $\beta$ is a self-aggregating protein that promotes synaptic dysfunction and death of mature neurons in $\mathrm{AD}$ (for review, see Mattson, 2000). Chronic infusion

Received Nov. 24, 2003; revised May 4, 2004; accepted May 5, 2004.

This work was supported by National Institute of Neurological Disorders and Stroke Grant NS-15076, a grant from the Alzheimer Association, and Alzheimer's Disease Research Center at Columbia University Grant AG08702. We are grateful for the helpful criticisms from Drs. Fiona Doetsch and James Goldman.

Correspondence should be addressed to Michael L. Shelanski, Columbia University College of Physicians and Surgeons, Department of Pathology, 630 West 168th Street, P\&S 15-402, New York, NY 10032. E-mail: mls7@columbia.edu.

DOI:10.1523/JNEUROSCI.0974-04.2004

Copyright $\odot 2004$ Society for Neuroscience $\quad$ 0270-6474/04/245439-06\$15.00/0 of $\mathrm{A} \beta$ into the lateral ventricles impairs spatial learning in mice (Nitta et al., 1997), and amyloid precursor protein (APP) mutant mice with amyloid deposition show impaired learning and memory loss (Hsiao et al., 1996). NSCs have the ability to grow in the presence of growth factors like epidermal growth factor (EGF) or basic FGF (bFGF) and the potential to differentiate into neurons, astrocytes, and oligodendrocytes. These cells have been isolated in vitro from several regions of embryonic and adult CNS, including the SVZ (Reynolds and Weiss, 1992; Gritti et al., 1999), cortex (Davis and Temple, 1994), spinal cord (Ray and Gage, 1994; Weiss et al., 1996), or midbrain (Bazan et al., 1998). However, there are only two regions where in vivo neurogenesis in the adult brain has been widely accepted: the SVZ, where cells migrate through the rostral migratory pathway and become neurons in the olfactory bulb (Altman and Das, 1965; Luskin, 1993; Lois and Alvarez-Buylla, 1994; Lois et al., 1996), and the subgranular layer of the dentate gyrus in the hippocampus, where cells migrate a short distance into the granular cell layer and differentiate into hippocampal granule cells (Altman and Das, 1965; Bayer et al., 1982; Kaplan and Bell, 1984; Stanfield and Trice, 1988; Kuhn et al., 1996).

In the present study, we find that treatment of hippocampal NSC progeny with $\mathrm{A} \beta$ peptide induces an increase in the number of newborn neurons with no changes in the rate of cell death or proliferation, suggesting that $\mathrm{A} \beta$ peptide could act on neuronal progenitors and promote their differentiation into neurons.

\section{Materials and Methods}

Neural stem cell cultures. Striata from embryonic day (E) 15 Sprague Dawley rat embryos or hippocampi from postnatal day (P) 0 Bl6 mice were dissected and mechanically dissociated. Cell suspensions were grown in a defined medium (DF12) composed of DMEM/F12 (1:1), 2 
mM L-glutamine, $1 \mathrm{~mm}$ sodium pyruvate, antibiotic-antimycotic (Invitrogen, Grand Island, NY), $0.6 \%$ glucose, $25 \mu \mathrm{g} / \mathrm{ml}$ insulin, 20 nM progesterone, $60 \mu \mathrm{M}$ putrescine, $30 \mathrm{~nm}$ sodium selenite (all from Sigma, St. Louis, MO), $100 \mu \mathrm{g} / \mathrm{ml}$ human transferrin (Roche, Indianapolis, IN), $20 \mathrm{ng} / \mathrm{ml}$ human recombinant EGF (Roche or Invitrogen, Chicago, IL) and bFGF (Upstate Biotechnology, Lake Placid, NY). The cells grew as free-floating aggregates (neurospheres) and were passaged by mechanical dissociation every 3-4 d. After a minimum of four passages, cells were plated at a density of $18,000 \mathrm{cells} / \mathrm{cm}^{2}$ on $15 \mu \mathrm{g} / \mathrm{ml}$ poly-L-lysine (Sigma) into coated $12 \mathrm{~mm}$ glass coverslips (VWR Scientific, Rochester, NY) or eight-well glass slide chambers (Nalge Nunc International, Naperville, IL). Cultures were maintained in DF12 and EGF or EGF plus bFGF for $3 \mathrm{~d}$ and then switched to DF12 without growth factors for longer culture periods. Immunocytochemical studies were performed at different time points between 3 and $10 \mathrm{~d}$ postplating (dpp). To analyze the effects of $\mathrm{A} \beta$ treatment, cells were treated with 1,5 , or $10 \mu \mathrm{M}$ of $\mathrm{A} \beta$ (American Peptide, Sunnyvale, CA). Parallel wells were maintained in DF12 without addition of peptide (untreated group). Immunocytochemical analyses were performed 1,4 , or $7 \mathrm{~d}$ after treatment.

Treatments with inhibitors. Genistein was obtained from Sigma. LY294002 was obtained from Biomol (Plymouth Meeting, PA), U0126 was obtained from Upstate Biotechnology, and the mouse monoclonal anti-human amyloid- $\beta$ protein (6E10) was obtained from Signet (Dedham, MA). Lyophilized, HPLC-purified A $\beta 1-42$ or 1-40 peptide was purchased from American Peptide, and A $\beta$ 25-35 was purchased from Bachem (Torrance, CA). Peptides were reconstituted in sterile water at a concentration of $400 \mu \mathrm{M}$ and incubated at $37^{\circ} \mathrm{C}$ for $3 \mathrm{~d}$ or $24 \mathrm{hr}$ to form aggregated $\mathrm{A} \beta$ or maintained at $4^{\circ} \mathrm{C}$ in soluble or nonaggregated form. Oligomeric and fibrillar $\mathrm{A} \beta$ were prepared using the method of Dahlgren et al. (2002).

NSC conditioned medium. Cells were treated with $\mathrm{A} \beta$ peptide beginning $3 \mathrm{dpp}$ for $4 \mathrm{~d}$. At $7 \mathrm{dpp}$, medium was removed and cells were fixed for immunostaining. This pretreated NSC conditioned medium (CM) was added to nontreated cells at $7 \mathrm{dpp}$ for a period of $24 \mathrm{hr}$ in presence or absence of $6 \mathrm{E} 10$ antibody to test whether the neurogenic effect was mediated through a soluble factor released to the medium for the cells in culture.

Indirect immunocytochemistry. Cells were fixed with $4 \%$ paraformaldehyde for $20 \mathrm{~min}$, permeabilized with an ethanol acetic acid solution (19:1) at $-20^{\circ} \mathrm{C}$ for $20 \mathrm{~min}$, blocked with $10 \%$ fetal bovine serum, and incubated with primary antibodies overnight at $4^{\circ} \mathrm{C}$. Sister cultures served as negative controls and were similarly processed, except for incubation without the primary antibody in each case. Immunofluorescence was used for detection of all antigens.

Primary antibodies. Monoclonal anti-nestin (clone Rat 401; 1:200) was obtained from Developmental Studies Hybridoma Bank (University of Iowa, Iowa City, IA). Polyclonal anti-glial fibrillary acid protein (1:500) was purchased from Dakopatts (Glostrup, Denmark). Monoclonal anti- $\beta$ tubulin isotype III (1:2000) and polyclonal anti- $\beta$-tubulin isotype III (1: 2000) were both from Covance (Richmond, CA). Polyclonal anti-O1 (1:5) was obtained from a hybridoma purchased from American Type Culture Collection (Manassas, VA). Monoclonal anti-bromodeoxyuridine (BrdU; 1:50) was obtained from Dako (High Wycombe, UK), and monoclonal antineuronal nuclei (NeuN) was obtained from Chemicon (Temecula, CA).

Secondary antibodies. For single labeling of neural antigens, goat anti mouse IgG $(\mathrm{H}+\mathrm{L})$ or goat anti-rabbit IgG $(\mathrm{H}+\mathrm{L})$ labeled with either AlexaFluor 568 or 488 were purchased from Molecular Probes (Eugene, OR).
Proliferation studies. To enable the detection of proliferating cells, 100 $\mu \mathrm{M} \mathrm{BrdU}$, an analog of thymidine, was added $24 \mathrm{hr}$ before cell culture fixation. After permeabilization with ethanol acetic solution (19:1), cells were treated with $2 \mathrm{~N} \mathrm{HCl}$ for $30 \mathrm{~min}$ at $4^{\circ} \mathrm{C}$ to denature DNA. Primary monoclonal antibody against BrdU (1:20; Dakopatts) was added for $1 \mathrm{hr}$ at room temperature and recognized by fluorescent secondary goat antimouse IgG $(\mathrm{H}+\mathrm{L})$ labeled with AlexaFluor 488. This method allows identification of cells that have duplicated their DNA in the last $24 \mathrm{hr}$.

Data analysis. Results are expressed as mean \pm SEM of direct counts of positive cells for each antibody from several independent experiments done in triplicates or quadruplicates. Where indicated, the data were normalized in relation to their own control group. In each culture, 25 predetermined visual fields were counted under fluorescence microscopy. The number of positive cells was corrected for total cells in the same area and counted with nuclear staining with Hoechst. Statistical analyses were performed using ANOVA and the Bonferroni post-test or Student's $t$ test. The difference was considered significant when $p \leq 0.05$. The statistical analysis was conducted using the Prism 3 program from GraphPad Software (San Diego, CA).

\section{Results}

\section{$\boldsymbol{\beta}$-Amyloid peptide increases the number of neurons in the} progeny of hippocampal stem cells

To test the effect of $\beta$-amyloid peptide on the fates of neural stem cells, NSC progeny from striatum and hippocampus were plated on poly-L-lysine, and varying concentrations of aggregated $\mathrm{A} \beta_{1-42}$ peptide were added at $2 \mathrm{hr}$ and 3, 7, and $10 \mathrm{dpp}$ for a period of $24 \mathrm{hr}$. Under all of these conditions, $\mathrm{A} \beta$ peptide increased the number of neurons, as identified by immunostaining with $\beta$-tubulin III antibody (Fig. $1 A$ ) with no changes in the number of apoptotic nuclei (Fig. $1 B$ ) or total cells in the culture (Fig. 1C). The increases varied from experiment to experiment, averaging a threefold increase in neurons compared with the controls. Results were similar in both hippocampal and striatal NSC progeny. The cells treated at $0 \mathrm{dpp}$ required higher concentrations of aggregated $A \beta_{1-42}$ for an optimal response, whereas "older" cells showed a peak response at $1 \mu \mathrm{M}$ (Fig. $1 A$ ). Based on these results, we focused on $7 \mathrm{dpp}$ hippocampal NSCs treated for $24 \mathrm{hr}$ with $1 \mu \mathrm{M} \mathrm{A} \beta$. At $7 \mathrm{dpp}$, NSC cultures contained a mix of 

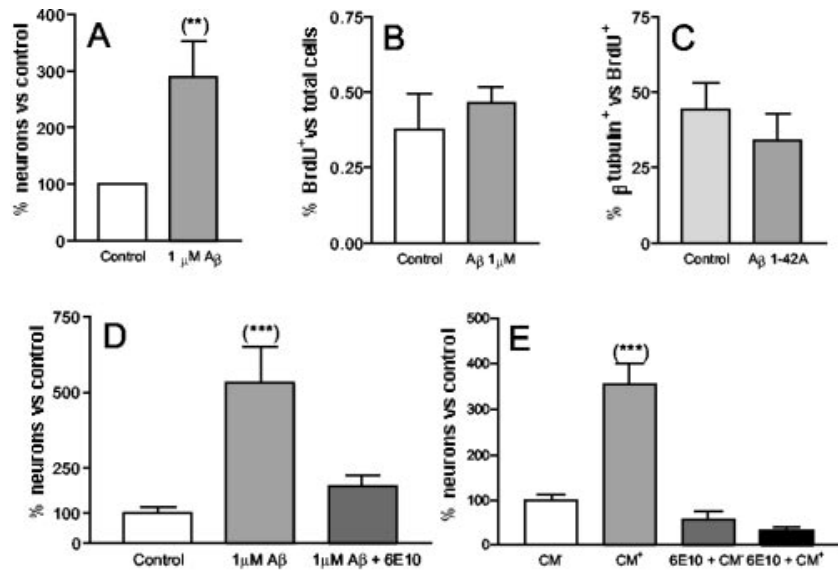

Figure 2. $\quad \beta$-Amyloid peptide $(1 \mu \mathrm{M})$ induces neurogenesis with no changes in proliferation, and its neurogenic effect is abolished by the $6 E 10 A \beta$ antibody. In $A$, we show mean \pm SEM of a total of 15 experiments in quadruplicate. In $B$, we can see that the increase in the number of neurons does not correlate with an increase in proliferative cells as measured by incorporation of BrdU. C, BrdU-positive cells differentiated into neurons at similar rates in treated and untreated cultures. $D$, The effect of treatment with $1 \mu \mathrm{m}$ aggregated $A \beta 1-42$ peptide was completely abolished by the $6 \mathrm{E} 10$ anti-A $\beta$ antibody (1:400 dilution). In $E$, we show the effect of exposure to conditioned medium for $24 \mathrm{hr}$ at $7 \mathrm{dpp}$. To obtain the CM, NSC was treated $1 \mu \mathrm{MA} \beta$ or maintained untreated (control) at $3 \mathrm{dpp}$. Four days later, medium was removed and added for $24 \mathrm{hr}$ to untreated cells at $7 \mathrm{dpp}$ with or without $6 \mathrm{E} 10$ antibody. The antibody abolished completely the $A \beta$-induced neurogenesis and the effect of $C M$. Results show mean $\pm S E M$ of one representative experiment of between two and four done in quadruplicate. Statistical significance of ANOVA followed by the Bonferroni post-test; ${ }^{* *} p<0.01 ;{ }^{* * *} p<0.001$ ).

progenitors and mature cells composed of 25-30\% neurons, $40-$ $50 \%$ astrocytes, $1-2 \%$ oligodendrocytes, and a variety of progenitors, mimicking, in part, the mature hippocampus. A doseresponse study showed that $1 \mu \mathrm{M} \mathrm{A} \beta$ was optimal in increasing neurogenesis (Fig. 1D). In 15 experiments, each done in quadruplicate, the increase in number of neurons averaged threefold $(290 \pm 65 \%)$ (Fig. 2A).

\section{$\mathrm{A} \boldsymbol{\beta}$ appears to act directly on neurogenic precursors}

The increase in the number of neurons was not attributable to an increase in the proliferating cells in the culture, because $24 \mathrm{hr}$ treatment with BrdU showed that the low number of proliferating cells in control cultures $(0.3 \pm 0.06 \%$, of total cells $n=3)$ did not change with $1 \mu \mathrm{M} \mathrm{A} \beta$ treatment (Fig. $2 B$ ) nor did the number of $\beta$ III-tubulin-positive neurons that incorporated BrdU (Fig. $2 C)$. This suggests that whether or not the cell was in the cell cycle within the preceding $24 \mathrm{hr}$ did not affect differentiation into neurons. The neurogenic effect of $\mathrm{A} \beta$ peptide was totally and specifically abolished in the presence of the anti-human $\beta$-amyloid antibody (6E10; 1:400) (Fig. 2D) and not in the presence of other similar IgG1 antibodies such as anti-NeuN (data not shown).

Many of the studies of $\mathrm{A} \beta$ peptide actions have used pure cultures of neurons or neuronal cell lines. In our experimental model, there is a complex mixture of cell types and stages of differentiation. Thus, it is possible that the observed increase in neurogenesis could result from $\mathrm{A} \beta$ action on cells other than the neuronal progenitors that, in turn, could produce an agent that induces neurogenesis. It is known that glial cells produce a variety of soluble factors (Chen et al., 1991; Engele et al., 1991; Kilpatrick et al., 1993; Dugan et al., 1995). To determine whether this occurs in our system, we tested the ability of CM from NSC progeny to induce neurogenesis. We obtained NSC conditioned medium
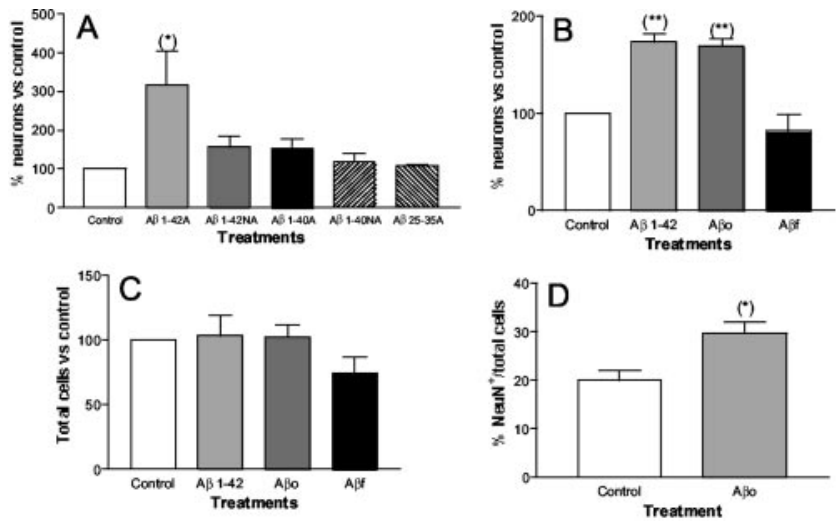

Figure 3. The neurogenic effect of $A \beta$ peptide is dependent of its state of aggregation. To test the effect of $A \beta$ aggregation in neurogenesis, we treated cells $(A)$ with $1 \mu \mathrm{MA} \beta 1-40$ and $1-42$ aggregated (1-40A or $1-42 \mathrm{~A}$ ) or nonaggregated (1-40NA or 1-42NA) and $A \beta 25-35$ aggregated (25-35A) for $24 \mathrm{hr}$ at $7 \mathrm{dpp}$. Only the $A \beta 1-42$ aggregated peptide had a neurogenic effect on the NSC progeny. In $B, A \beta$ produced by the method of Dahlgren et al. (2002) was used. Only the oligomeric peptide $(A \beta 0)$ and 1-42 aggregated had a neurogenic effect. $C$, Fibrillar $A \beta(A \beta f)$ caused a statistically insignificant decrease in the total number of cells. $\ln D$, we show the increase of neurons with the $A \beta 0$ counting NeuN-positive cells, another marker of neurons. The graphs represent mean \pm SEM of four $(A)$ or three $(B-D)$ different experiments done in quadruplicate. ANOVA followed by Bonferroni post-test; ${ }^{*} p<0.05$; ${ }^{* *} p<0.01$.

from cells treated with $A \beta$ for $4 \mathrm{~d}$ starting at $3 \mathrm{dpp}$. In this condition, $1 \mu \mathrm{M} \mathrm{A} \beta$ peptide induced an increase of $360 \pm 117 \%$ versus control ( $n=4$ independent experiments in quadruplicates). We then used the CM to replace the medium on $7 \mathrm{dpp}$ cultures that had not been exposed to $A \beta$. An increase in neurogenesis was seen in the cells exposed to the conditioned media from $A \beta$-treated cultures but not in those exposed to $C M$ from control cultures (Fig. $2 E$ ). However, addition of anti-A $\beta$ antibody blocked this increase, suggesting that the $\mathrm{CM}$-induced neurogenesis was caused by residual $\mathrm{A} \beta$ in the $\mathrm{CM}$ and that the neurogenic effect of $\mathrm{A} \beta$ peptide was directly on the progenitor cells (Fig. $2 E$ ). In two experiments, $\mathrm{CM}$ were centrifuged at high speed $(100,000 \times g$ for $1 \mathrm{hr})$ before use. The centrifuged CM maintained neurogenic activity, suggesting that smaller rather than larger $\mathrm{A} \beta$ aggregates are the active component.

\section{$\mathrm{A} \boldsymbol{\beta}$ form and aggregation state are critical for the neurogenic effect of $\mathrm{A} \boldsymbol{\beta}$ peptide}

The persistence of $\mathrm{A} \beta$-induced neurogenic activity in $\mathrm{CM}$ from which larger $A \beta$ aggregates had been removed by centrifugation suggested that the aggregation state of $A \beta$ might play a significant role in its effects. Cleavage of the APP produces two major forms of the $A \beta$ peptide, $A \beta_{1-40}$ and $A \beta_{1-42}$. The experiments in the previous sections were conducted using $A \beta_{1-42}$, which had been aggregated for $3 \mathrm{~d}$. In a series of experiments described in this section, we examined the ability of $A \beta_{1-40}$ and $A \beta_{1-42}$ peptides either aggregated or freshly prepared (unaggregated) to induce neurogenesis. Only aggregated $\mathrm{A} \beta_{1-42}(1 \mu \mathrm{M})$ was able to induce neurogenesis. Neither freshly prepared $A \beta_{1-42}$ nor $A \beta_{1-40}$ (aggregated or not) increased the percentage of neurons (Fig. $3 A$ ). To test the effect of $\mathrm{A} \beta_{25-35}$ in our system and compare it with the results of Haughey et al. (2002a), we treated cultures at $7 \mathrm{dpp}$ for $24 \mathrm{hr}$ with aggregated $\mathrm{A} \beta_{25-35}$ with no increase in the number of $\beta$-tubulin III-positive cells (Fig. $3 A$ ) and no change in the total number of cells or apoptotic nuclei (data not shown). We then prepared $\mathrm{A} \beta_{1-42}$ using a protocol that allows enrichment for either oligomers or fibrils (Dahlgren et al., 2002). The treatment of 
NSCs with $1 \mu \mathrm{M}$ oligomeric $\mathrm{A} \beta_{1-42}$ caused a similar increase in neurogenesis than seen with $\mathrm{A} \beta_{1-42}$ that had been aggregated for $3 \mathrm{~d}$, with no increase in apoptotic nuclei or change in total cell number (Fig. $3 B, C)$.

To exclude the possibility that $\beta$-tubulin III was detecting non-neuronal cells, we also stained parallel experiments with the neuronal marker NeuN. As with $\beta$-tubulin III, we saw a significant increase in the total number of neurons in response to $A \beta$. A typical experiment is shown in Figure 3D.

\section{The neurogenic effect of $A \beta$ is mediated through tyrosine- kinase phosphorylation and the MAPK (mitogen-activated protein kinase) pathway}

To evaluate the possible signal transduction pathways involved in $\mathrm{A} \beta$-induced neurogenesis, we used several inhibitors of pathways known to be involved in neurogenesis in other systems. These included Genistein, an inhibitor of tyrosine kinases (TyrK) and a competitive inhibitor of ATP in other protein kinase reactions. At $7 \mathrm{dpp}$, NSC progeny were treated for $24 \mathrm{hr}$ with 1,5 , and $10 \mu \mathrm{M}$ Genistein. At these concentrations, the inhibitor did not increase the number of apoptotic nuclei nor did it change the number of neurons observed versus controls. When $1 \mu \mathrm{M} \mathrm{A} \beta$ was added in the presence of Genistein, the increase of neurons mediated by $\mathrm{A} \beta$ was abolished (Fig. $4 A$ ). Similarly, treatment with U0126, a selective inhibitor of MEK (MAP kinase kinase), did not induce any change in total neurons in the culture (Fig. $4 B$ ) but was able to inhibit the $\mathrm{A} \beta$-induced increase in neurons. In contrast, LY294002, a selective inhibitor of PI3K (phosphatidylinositol 3-kinase), was unable to inhibit $\mathrm{A} \beta$-induced neurogenesis (Fig. 4C).

\section{Discussion}

Our working hypothesis in initiating this study was that $\mathrm{A} \beta$ would inhibit neurogenesis and prevent reparative processes. The results presented here suggest that, at least in cell culture, the opposite occurs. Our results are at variance with two previous studies (Haughey et al., 2002a,b) that show that A $\beta$ treatment impairs the proliferation and differentiation of NSCs to neurons. Our experiments differ from theirs in the form of $A \beta$ used, in the type of NSC culture used, and in the concentrations of A $\beta$. Any or all of these could explain the differences in results. For example, in one report, the $A \beta$ peptide used was aggregated $A \beta_{25-35}$ (Haughey et al., 2002a). The $\mathrm{A} \beta_{25-35}$ peptide does not occur naturally but has been shown to mimic the adverse effects of $\mathrm{A} \beta_{1-42}$ in several studies. In fact, our results show that aggregated $\mathrm{A} \beta_{25-35}$ does not affect the neurogenic rate in our system when added for $24 \mathrm{hr}$ at $7 \mathrm{dpp}$. In the study by Haughey et al. (2002b), $5 \mu \mathrm{M} \mathrm{A} \beta$ decreased the area of radial outgrowth of cells from neurospheres because of the reduced adhesion to the substrate. In our system, neither cells plated onto $\mathrm{A} \beta$ peptide nor treatment with 1 , 5, or $10 \mu \mathrm{M}$ aggregated $A \beta_{1-42}$ affected the radial outgrowth (data not shown). However, when our hippocampal NSCs were plated onto the peptide, no change in the number of neurons was observed, but apoptosis increased in a concentration-dependent manner, showing a toxic effect on NSCs in the culture similar to that obtained by Haughey et al. (2002) (data not shown). The previous studies also show a threefold increase in the number of apoptotic cells, many of which are
E-NCAM(also known as polysialylated form of neurol cell adhesion molecule)-positive neurons (Haughey et al., 2002b), whereas there is no significant apoptosis in our cultures. Haughey et al. (2002b) performed their studies on neurospheres from 8- to 10 -week-old cortical tissues from human fetuses, and we obtained ours from P1 mouse hippocampus. Active neurogenesis is limited to discrete regions of CNS of adult mammals. In fact, NSCs from hippocampus or spinal cord give rise to neurons after grafting to the dentate gyrus but not after graft to other CNS regions (Shihabuddin et al., 2000). The regional differences could be a function of hippocampal astrocytes that may provide a unique niche for adult neurogenesis (Haydon, 2001; Seri et al., 2001; Cheng et al., 2002; Kempermann et al., 2002; Song et al., 2002a,b; Monje and Palmer, 2003). However, our data with NSC conditioned medium demonstrate that soluble factors released into the medium by NSC progeny are not responsible for neurogenic effect of $\mathrm{A} \beta$ peptide.

Apoptosis is a common feature in regions of neurogenesis (Biebl et al., 2000). Cell death is several-fold higher in neurogenic areas than in other areas of the brain, and cells die during all phases of neurogenesis: stem cell proliferation, progenitor migration, and neuronal differentiation. Despite these neuronal losses, neuronal cell numbers in the dentate gyrus increase continuously, suggesting that production outweighs loss over the life of the animal (Kaplan and Hinds, 1977; Bayer et al., 1982). It has been proposed that cell death or damage releases signals that trigger neurogenesis and cell replacement in vivo (Snyder et al., 1997; Kokaia and Lindvall, 2003). These lesions could create a permissive microenvironment for neuronal differentiation through re-expression of developmental signals ordinarily available only during embryonic neurogenesis. In our system, we did not observe any significant loss of the number of total cells, and the number of apoptotic nuclei did not increase after $A \beta$ treatment. However, we cannot completely discard the possibility that a small increase in the apoptotic or necrotic death of mature neurons, perhaps concealed by the variation in our experiments, could start a cascade of events that would increase neurogenesis. The fact that when undifferentiated NSCs were grafted into 1-methyl-4-phenyl-1,2,3,6-tetrahydropyridine damaged brains, the majority of new dopaminergic neurons were "rescued" host cells (Ourednik et al., 2002) opens the possibility that undifferentiated progenitors might spontaneously express neuroprotective signals, and that NSCs might have an inherent capacity to alter the host environment, reactivating or preserving dysfunctional endogenous neurons. Previous studies (Ciaroni et al., 2002) describe a correlation between proliferation and cell survival. If proliferation is inhibited, the rate of survival increases. This suggests a possible link between neurogenesis and regulation of cell number. We see very low numbers of proliferative cells in our cultures ( $\sim 0.3 \%$ of total cells) (Fig. $2 B, C$ ) with no significant 
differences between control and $\mathrm{A} \beta$-treated cultures. These data and the inability of conditioned medium to induce an increase in neurogenesis suggest that the effect of $A \beta$ is directly on postmitotic neuronal progenitor cells driving their differentiation toward neurons.

The dependence of the neurogenic effect of $A \beta$ on the state of aggregation of $A \beta$ suggests that the formation of new neurons is more likely to be induced by the "soluble" forms of $A \beta$ than by the $\mathrm{A} \beta$ that has been organized into senile plaques. One possible interpretation of these data is that in earlier stages of Alzheimer's disease, when the excess of $A \beta$ is enough to form oligomeric but not fibrillar aggregates, the oligomers (Dahlgren et al., 2002; Kim et al., 2003) could activate a compensatory mechanism to replace lost or damaged neurons by increasing the differentiation of neuronal progenitors into new neurons. As time passes and senile plaques are formed, the balance could shift to fibrillar $A \beta$ that could be more neurotoxic.

The inhibition of neurogenesis by Genistein suggests that tyrosine kinases are involved in this process. These kinases include the classical neurotrophin receptors that are essential in nervous system development (for review, see Chao et al., 2003). The experiments with conditioned media point to a direct effect of the $\mathrm{A} \beta$ peptide on the target cell and not to the release of a growth factor that would then act on these receptors. However, it is possible that the interaction of $A \beta_{\circ}$ with another surface protein (Gong et al., 2003) could activate TyrK and drive neurogenesis. We examined two signaling pathways downstream of TyrK. Inhibition of the PI3K system did not affect neurogenesis. PI3K plays an important role in the protection from apoptosis (Carpenter and Cantley, 1996), but its inhibition did not increase apoptosis. In contrast, inhibition of the ERK (extracellular signalregulated kinase) pathway blocked neurogenesis. The ERK pathway has been implicated in the regulation of cell growth and proliferation, in differentiation, and in apoptosis (Chang and Karin, 2001). Additional examination of its role in neurogenesis in this system is needed to understand the events downstream of TyrK activation. A better understanding of $A \beta$ on these pathways has the potential to provide targets for therapeutic interventions to prevent $\mathrm{A} \beta$-induced neuronal loss and encourage neuronal replacement.

\section{References}

Altman J, Das GD (1965) Post-natal origin of microneurones in the rat brain. Nature 207:953-956.

Bayer SA, Yackel JW, Puri PS (1982) Neurons in the rat dentate gyrus granular layer substantially increase during juvenile and adult life. Science 216:890-892.

Bazan E, Lopez-Toledano M, Redondo C, Alcazar A, Mena M, Paino C, Herranz A (1998) Characterization of rat neural stem cells from embryonic striatum and mesencephalon during in vitro differentiation. In: Understanding glial cells (Castellano B, ed), pp 91-101. Kluwer Academic.

Biebl M, Cooper CM, Winkler J, Kuhn HG (2000) Analysis of neurogenesis and programmed cell death reveals a self-renewing capacity in the adult rat brain. Neurosci Lett 291:17-20.

Carpenter CL, Cantley LC (1996) Phosphoinositide 3-kinase and the regulation of cell growth. Biochim Biophys Acta 1288:M11-M16.

Chang L, Karin M (2001) Mammalian MAP kinase signalling cascades. Nature 410:37-40.

Chao MV (2003) Neurotrophins and their receptors: a convergence point for many signalling pathways. Nat Rev Neurosci 4:299-309.

Chen JK, Yao LL, Jenq CB (1991) Mitogenic response of rat Schwann cells to fibroblast growth factors is potentiated by increased intracellular cyclic AMP levels. J Neurosci Res 30:321-327.

Cheng Y, Black IB, DiCicco-Bloom E (2002) Hippocampal granule neuron production and population size are regulated by levels of bFGF. Eur J Neurosci 15:3-12.

Ciaroni S, Cecchini T, Ferri P, Ambrogini P, Cuppini R, Riccio M, Lombardelli G, Papa S, Del Grande P (2002) Impairment of neural precursor proliferation increases survival of cell progeny in the adult rat dentate gyrus. Mech Aging Dev 123:1341-1352.

Dahlgren KN, Manelli AM, Stine Jr WB, Baker LK, Krafft GA, LaDu MJ (2002) Oligomeric and fibrillar species of amyloid-beta peptides differentially affect neuronal viability. J Biol Chem 277:32046-32053.

Davis AA, Temple S (1994) A self-renewing multipotential stem cell in embryonic rat cerebral cortex. Nature 372:263-266.

Dugan LL, Bruno VM, Amagasu SM, Giffard RG (1995) Glia modulate the response of murine cortical neurons to excitotoxicity: glia exacerbate AMPA neurotoxicity. J Neurosci 15:4545-4555.

Engele J, Schubert D, Bohn MC (1991) Conditioned media derived from glial cell lines promote survival and differentiation of dopaminergic neurons in vitro: role of mesencephalic glia. J Neurosci Res 30:359-371.

Gong Y, Chang L, Viola KL, Lacor PN, Lambert MP, Finch CE, Krafft GA, Klein WL (2003) Alzheimer's disease-affected brain: presence of oligomeric A beta ligands (ADDLs) suggests a molecular basis for reversible memory loss. Proc Natl Acad Sci USA 100:10417-10422.

Gould E, Beylin A, Tanapat P, Reeves A, Shors TJ (1999) Learning enhances adult neurogenesis in the hippocampal formation. Nat Neurosci 2:260-265.

Gritti A, Frolichsthal-Schoeller P, Galli R, Parati EA, Cova L, Pagano SF, Bjornson CR, Vescovi AL (1999) Epidermal and fibroblast growth factors behave as mitogenic regulators for a single multipotent stem cell-like population from the subventricular region of the adult mouse forebrain. J Neurosci 19:3287-3297.

Haughey NJ, Liu D, Nath A, Borchard AC, Mattson MP (2002a) Disruption of neurogenesis in the subventricular zone of adult mice, and in human cortical neuronal precursor cells in culture, by amyloid beta-peptide: implications for the pathogenesis of Alzheimer's disease. Neuromolecular Med 1:125-135.

Haughey NJ, Nath A, Chan SL, Borchard AC, Rao MS, Mattson MP (2002b) Disruption of neurogenesis by amyloid beta-peptide, and perturbed neural progenitor cell homeostasis, in models of Alzheimer's disease. J Neurochem 83:1509-1524.

Haydon PG (2001) GLIA: listening and talking to the synapse. Nat Rev Neurosci 2:185-193.

Hsiao K, Chapman P, Nilsen S, Eckman C, Harigaya Y, Younkin S, Yang F, Cole G (1996) Correlative memory deficits, Abeta elevation, and amyloid plaques in transgenic mice. Science 274:99-102.

Kaplan MS, Bell DH (1984) Mitotic neuroblasts in the 9-day-old and 11month-old rodent hippocampus. J Neurosci 4:1429-1441.

Kaplan MS, Hinds JW (1977) Neurogenesis in the adult rat: electron microscopic analysis of light radioautographs. Science 197:1092-1094.

Kempermann G, Kuhn HG, Gage FH (1998) Experience-induced neurogenesis in the senescent dentate gyrus. J Neurosci 18:3206-3212.

Kempermann G, Gast D, Gage FH (2002) Neuroplasticity in old age: sustained fivefold induction of hippocampal neurogenesis by long-term environmental enrichment. Ann Neurol 52:135-143.

Kilpatrick TJ, Talman PS, Bartlett PF (1993) The differentiation and survival of murine neurons in vitro is promoted by soluble factors produced by an astrocytic cell line. J Neurosci Res 35:147-161.

Kim HJ, Chae SC, Lee DK, Chromy B, Lee SC, Park YC, Klein WL, Krafft GA, Hong ST (2003) Selective neuronal degeneration induced by soluble oligomeric amyloid beta protein. FASEB J 17:118-120.

Kokaia Z, Lindvall O (2003) Neurogenesis after ischaemic brain insults. Curr Opin Neurobiol 13:127-132.

Kuhn HG, Dickinson-Anson H, Gage FH (1996) Neurogenesis in the dentate gyrus of the adult rat: age-related decrease of neuronal progenitor proliferation. J Neurosci 16:2027-2033.

Kuhn HG, Palmer TD, Fuchs E (2001) Adult neurogenesis: a compensatory mechanism for neuronal damage. Eur Arch Psychiatry Clin Neurosci 251:152-158.

Lois C, Alvarez-Buylla A (1994) Long-distance neuronal migration in the adult mammalian brain. Science 264:1145-1148.

Lois C, Garcia-Verdugo JM, Alvarez-Buylla A (1996) Chain migration of neuronal precursors. Science 271:978-981.

Luskin MB (1993) Restricted proliferation and migration of postnatally 
generated neurons derived from the forebrain subventricular zone. Neuron 11:173-189.

Mattson MP (2000) Apoptosis in neurodegenerative disorders. Nat Rev Mol Cell Biol 1:120-129.

Monje ML, Palmer T (2003) Radiation injury and neurogenesis. Curr Opin Neurol 16:129-134.

Nitta A, Fukuta T, Hasegawa T, Nabeshima T (1997) Continuous infusion of beta-amyloid protein into the rat cerebral ventricle induces learning impairment and neuronal and morphological degeneration. Jpn J Pharmacol 73:51-57.

Ourednik J, Ourednik V, Lynch WP, Schachner M, Snyder EY (2002) Neural stem cells display an inherent mechanism for rescuing dysfunctional neurons. Nat Biotechnol 20:1103-1110.

Ray J, Gage FH (1994) Spinal cord neuroblasts proliferate in response to basic fibroblast growth factor. J Neurosci 14:3548-3564.

Reynolds BA, Weiss S (1992) Generation of neurons and astrocytes from isolated cells of the adult mammalian central nervous system. Science 255:1707-1710.

Seri B, Garcia-Verdugo JM, McEwen BS, Alvarez-Buylla A (2001) Astrocytes give rise to new neurons in the adult mammalian hippocampus. J Neurosci 21:7153-7160.

Shihabuddin LS, Horner PJ, Ray J, Gage FH (2000) Adult spinal cord stem cells generate neurons after transplantation in the adult dentate gyrus J Neurosci 20:8727-8735.

Shors TJ, Miesegaes G, Beylin A, Zhao M, Rydel T, Gould E (2001) Neurogenesis in the adult is involved in the formation of trace memories. Nature 410:372-376.

Snyder EY, Yoon C, Flax JD, Macklis JD (1997) Multipotent neural precursors can differentiate toward replacement of neurons undergoing targeted apoptotic degeneration in adult mouse neocortex. Proc Natl Acad Sci USA 94:11663-11668.

Song H, Stevens CF, Gage FH (2002a) Astroglia induce neurogenesis from adult neural stem cells. Nature 417:39-44

Song HJ, Stevens CF, Gage FH (2002b) Neural stem cells from adult hippocampus develop essential properties of functional CNS neurons. Nat Neurosci 5:438-445.

Stanfield BB, Trice JE (1988) Evidence that granule cells generated in the dentate gyrus of adult rats extend axonal projections. Exp Brain Res 72:399-406

Weiss S, Dunne C, Hewson J, Wohl C, Wheatley M, Peterson AC, Reynolds BA (1996) Multipotent CNS stem cells are present in the adult mammalian spinal cord and ventricular neuroaxis. J Neurosci 16:7599-7609.

Yankner BA (2000) The pathogenesis of Alzheimer's disease. Is amyloid beta-protein the beginning or the end? Ann NY Acad Sci 924:26-28. 